\title{
Strategic Alliances In Public Accounting Firms
}

\author{
Huldah A. Ryan, Ph.D., Iona College, USA \\ Charles J. Cante, Ph.D., Iona College, USA \\ Robert G. Strittmatter, MBA, CPA, Iona College, USA \\ Vincent J. Calluzzo, Ph.D., Iona College, USA \\ Caitlin R. Maxwell, BBA, Iona College, USA
}

\begin{abstract}
The decade of the 1990s saw the emergence of the concept of the strategic alliance and its significant growth in both numbers and diversity of alliance areas as well as its impact on business performance in terms of new service or product introductions and/or increases in revenue, profit, volume or market share. Public accounting (CPA) firms have participated in such alliances especially during times of staffing shortages and seasonal peak periods, but their participation has not been well reported in the literature. This study examines the state of strategic alliances in public accounting firms. The topic is particularly relevant now in light of the greater responsibilities placed on management since the passage of the Sarbanes-Oxley Act, and the issuance recently of two Statements of Financial Accounting Standards (SFAS No. 157 in 2006 and SFAS No. 159 in 2007) which give companies the option to report certain financial assets and liabilities at fair value. These additional responsibilities may include the restructuring and restatement of financial reports to more accurately reflect the financial position and results of operations of a business. This has resulted in a greater demand for accounting services which some CPA firms were not able to provide. The findings reveal that participation in strategic alliances enables accounting firms to pool their resources, increase revenues, build a larger knowledge support system to serve a wider clientele, and compete with larger firms both nationally and on a global basis.
\end{abstract}

\section{INTRODUCTION}

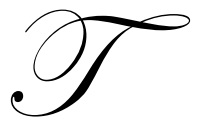

he increase in the use of strategic alliances has enabled public accounting (CPA) firms to address some of the major challenges and issues that confront them in their efforts to provide the product or service to clients/customers that gives them a competitive advantage in the marketplace. Strategic alliances are part of the total quality management (TQM) strategy which focuses on the long-term success of the organization. Specifically, they are formal arrangements between two or more entities to gain access to muchneeded resources that each party may not possess. The goal is to provide the product or service to clients/customers that gives them a competitive advantage, and to gain access to new distribution channels and sources of supply, financing, expertise and intellectual property that exist in today's changing deal environment. This is especially relevant with the rapid expansion of international competition and globalization. Thus accounting firms have realized the need to utilize alliance partners to pursue opportunities even beyond national borders. The passage of the Sarbanes-Oxley Act of 2002 with its accompanying boom in compliance work, and the requirement for mandatory adoption of fair value accounting in reporting financial instruments as of January 1, 2008, have forced many CPA firms to outsource specialized engagements to firms "upstream" or "downstream" that have the expertise to perform them. The synergies derived from such collaborations, where the total benefits from the alliances exceed the individual benefits, are compounded and can lead to the overall success and growth of each firm in the alliance.

In this paper we examine the state of strategic alliances in public accounting (CPA) firms. This topic is particularly relevant especially in light of the greater responsibilities placed on management since the passage of the Sarbanes-Oxley Act, and the issuance recently of two Statements of Financial Accounting Standards (SFAS No. 157 
in 2006 and SFAS No. 159 in 2007) which give companies the option to report certain financial assets and liabilities at fair value. These additional responsibilities may include the restructuring and restatement of financial reports to more accurately reflect the financial position and the results of operations of a business. This has created a greater demand for accounting services which some CPA firms may not be able to provide. Further, the enactment of these new standards is another step in the harmonization of US accounting standards (GAAP) and international standards (IFRS).

\section{THE NATURE OF STRATEGIC ALLIANCES}

Strategic alliances have been a popular topic of research in management's responses to external environmental influences. These collaborations involve combining knowledge and resources, which enable organizations to penetrate markets within and beyond national borders. The need for alliances exists throughout all stages of firm development. They are formed as a reaction to organization resource lack, and fulfill specific purposes including the need to:

- Access sources of financial and technological know-how during the conceptual and developmental stage (Hwang and Park, 2007);

- $\quad$ Gain entry into marketing and distribution channels during the commercialization stage (Brannback, 1997 and Kotler, 2000);

- $\quad$ Develop firm capabilities in order to achieve economies of scale during the growth period (Kazanjian and Drazin, 1990); and

- Gain access to radical new technologies that could be used to thwart risks and uncertainty that may occur during the stability stage (Huang and Park, 2007).

The expansion of globalization and the development of international trade and finance have also imposed new challenges for organizations as they seek to compete and survive. Rapid changes in technology have placed organizations in closer contact with one another and have also forced them to compete on an international level. Strategic alliances have become a necessity for organizations to gain competitive advantage in today's complex and changing markets. This has led to an upsurge in the number of alliances established in the United States since 1997. These alliances increased by more than 25 percent annually between 1997 and 2001 . Organizations have been able to gain access to new markets by utilizing the technologies and other resources owned by their alliance partners.

CPA firms in particular have been faced with a number of issues, challenges and concerns as they strive to meet their clients' demands and maintain their practices. Jim Metzler (AICPA Vice President for Small Business Interests) noted that CPA firms have participated in alliances for several reasons including client retention, sourcing (second firm work) which has become plentiful especially due to the need for Sarbanes-Oxley compliance, and the need for independence and for acquiring specialized services. Additionally, CPA firms face the need for increased services during peak periods, often for tax preparation when they may become overwhelmed with new changes and work assignments. Strategic alliances provide CPA firms with the needed resources and expertise to retain clients and even expand their services offered while benefiting from cost savings. Alliances enable firms to share knowledge and increase their market effectiveness, create and/or develop customer value by the services they provide to clients, while also maintaining or improving their bottom lines.

\section{METHODOLOGY}

A 16-point survey instrument was developed to investigate the penetration of strategic alliances in the public accounting profession. The survey was mailed to the listing of 975 U.S. CPA firms registered with the Public Company Accounting Oversight Board (PCAOB) as of June 2008. The major objective of the survey was to gather information and develop a database that could be used by CPA firms in making decisions that could advance the profession and improve its effectiveness in providing financial information services to users. The survey requested information on the participation of each firm in alliances, the major reasons for participation, the types of services provided by alliance partners, and the firm's opinion of the outcomes of the alliances. The sample period was chosen because it seemed an ideal time to investigate how CPA firms and their clients were responding to the new regulations established for financial reporting as well as compliance with the Sarbanes-Oxley Act since its passage 
in 2002. The mailing resulted in 76 responses with data provided primarily by the managing partners, audit partners or other partners of the firms. An initial examination of the responses revealed that 74 surveys were found to be usable, which corresponds to a 7.6 percent response rate for data analysis.

\section{RESULTS OF ANALYSES}

We used each firm's total revenue as a proxy for the size of the respondents. As indicated in Table 1, the majority of firms in the sample earned less than \$10 million during the fiscal years 2006 and 2007 (85.1\% and $81.1 \%$ respectively). During $200612.1 \%$ of the firms earned between $\$ 10$ million and \$50 million, while in 2007 the percentage of firms earning within this range was $16.2 \%$ of the total sample.

Table 1- Revenues Earned by Sample Firms

\begin{tabular}{|l|c|c|c|c|}
\hline \multicolumn{1}{|c|}{ Firm Size } & \multicolumn{2}{c|}{$\mathbf{2 0 0 6}$} & \multicolumn{2}{c|}{$\mathbf{2 0 0 7}$} \\
\hline Less than \$10 million & No. & \% & No. & \% \\
\hline Between \$10 million and \$50 million & 63 & 85.1 & 60 & 81.1 \\
\hline Between \$50 million and \$100 million & 9 & 12.1 & 12 & 16.2 \\
\hline Between \$100 million and \$250 million & 1 & 1.4 & 1 & 1.4 \\
\hline Total Responses & 1 & 1.4 & 1 & 1.4 \\
\hline
\end{tabular}

Table 2 shows results for fiscal year 2007 with 23 or $31.1 \%$ of the firms reporting that they participated in strategic alliances. Eighteen firms indicated that they were involved with one or two alliance partners, three firms had three alliance partners, and two firms reported that they collaborated with five alliance partners. Thus, 23 firms in the sample of 74 respondents participated in a total of 46 strategic alliances during fiscal year 2007.

Table 2- Firm Participation in Strategic Alliances

\begin{tabular}{|c|c|c|}
\hline Number of Alliances & Number of Firms & \% of Firms with Alliances \\
\hline 0 & 51 & 68.9 \\
\hline 1 & 9 & 12.2 \\
\hline 2 & 9 & 12.2 \\
\hline 3 & 3 & 4.0 \\
\hline 4 & 0 & 0.0 \\
\hline 5 & 2 & 2.7 \\
\hline & 74 & $100 \%$ \\
\hline
\end{tabular}

Note should be taken of the relatively high percentage of firms which reported that they had no alliances (68.9\%). As firms registered with the Public Company Accounting Oversight Board (PCAOB), created by the SEC to monitor public auditors, these firms apparently have the expertise necessary to perform the audit services that client companies request in accordance with SOX/PCAOB regulations. It is possible that they did not need to outsource any service in relation to these audits.

Firms were asked about the relative size of their alliance partners in terms of revenue generated. According to their estimates, $72 \%$ of the partners generated revenues of up to $\$ 100$ million, another $20 \%$ earned between $\$ 250$ million and $\$ 1$ billion, while $8 \%$ of the partners earned between $\$ 1$ billion and $\$ 5$ billion. These numbers indicate that the alliance partners generated relatively larger amounts of revenues than the firms in the study did. This is understandable given the types of services that were provided by the alliance partners as shown in Table 3 . 
Table 3 - Strategic Alliances With Service Providers

\begin{tabular}{|l|c|c|}
\hline \multicolumn{1}{|c|}{$\begin{array}{c}\text { Type of Service } \\
\text { from Alliance Partners }\end{array}$} & $\begin{array}{c}\text { Number of Each Type } \\
\text { of Service Received }\end{array}$ & $\begin{array}{c}\text { Percentage of Firms } \\
\text { Receiving Service }\end{array}$ \\
\hline Independent Auditing & 47 & 33.8 \\
\hline Non-Assurance Auditing & 22 & 15.8 \\
\hline Compilation and Review & 15 & 5.8 \\
\hline IT Support & 8 & 5.7 \\
\hline CPE & 8 & 5.0 \\
\hline Forensic Accounting & 7 & 5.0 \\
\hline Litigation Support & 7 & 3.6 \\
\hline SOX Compliance & 5 & 3.6 \\
\hline Tax Preparation & 5 & 2.9 \\
\hline Bookkeeping & 4 & 2.9 \\
\hline Peer Review & 4 & 2.2 \\
\hline Financial/Estate Planning & 3 & 0.8 \\
\hline Budgeting & 1 & 2.2 \\
\hline Other Services & 3 & $100 \%$ \\
\hline Total & 139 & \\
\hline
\end{tabular}

Independent auditing, non-assurance auditing, and compilation and review services were the major types of services received by survey respondents during fiscal year 2007, followed by the need for IT (Information Technology) support, and CPE (Continuing Professional Education), forensic accounting and litigation support services. The outsourcing of auditing services, particularly independent auditing services, is necessary if the firm is to comply with SOX financial reporting regulations. In addition, many firms outsource their non-assurance/internal audit work, especially for operations, compliance and efficiency to other firms, and these firms cannot be the client's independent auditors at the same time. This could explain the relatively low demand/need for services related to SOX compliance that could be part of the work requested in any contract for non-assurance services.

Respondents were asked to rate the aggregate benefits of the alliances compared to the expectations set forth in the alliance agreements, as well as the cost committed to the alliances compared to the forecast at the onset of the alliances. A summary of their responses is presented in Table 4, Panels A and B.

Table 4 -Aggregate Benefits and Costs of Strategic Alliances

\begin{tabular}{|c|c|c|}
\hline Panel A: Aggregate Benefits & Number of Alliances & Percentage \\
\hline Exceeded Expectations & 13 & 43.3 \\
\hline Met Expectations & 13 & 43.3 \\
\hline Marginally Acceptable & 4 & 13.3 \\
\hline Did Not Meet Expectations & 0 & 0.0 \\
\hline Panel B: Aggregate Costs & Number of Alliances & Percentage \\
\hline Significantly Higher & 2 & 6.9 \\
\hline Higher & 2 & 6.9 \\
\hline As Expected & 25 & 86.2 \\
\hline Lower & 0 & 0.0 \\
\hline Significantly Lower & 0 & 0.0 \\
\hline
\end{tabular}

It is evident from the responses given in Table 4, Panel A, that overall the benefits derived from the strategic alliances in which the CPA firms in the sample participated either exceeded or met their expectations (86.6\%). Only $13.3 \%$ of the collaborations resulted in marginally acceptable benefits to the firms. Consistent with these results, the firms reported that the costs incurred in these arrangements were in line with their forecasts. As shown in Panel B, the aggregate costs incurred in 86.2 percent of the alliances were as expected, while in $13.8 \%$ of the alliances the costs were either higher or significantly higher than estimated. 
Firms participating in 43 alliances reported that they intend to continue into another period with their partners, while in the other 3 cases respondents reported that they intend to discontinue the relationship with their current partners and engage new partners. This is consistent with their responses to the question on whether they intend to discontinue their alliances at the conclusion of the term. All respondents reported that none of the alliances would be discontinued because they had not accomplished their objectives/purpose. Instead, $88 \%$ of participants reported an increase in business relative to revenues and/or market share, while the remaining $22 \%$ reported no change in business activity.

Table 5 - Major "Satisfactions/Dissatisfactions" From Strategic Alliances

\begin{tabular}{|l|l|}
\hline \multicolumn{1}{|c|}{ Satisfactions } & \multicolumn{1}{c|}{ Dissatisfactions } \\
\hline Ability to exchange ideas & Background and skill not as advertised \\
\hline Ability to serve more clients & Billings not always timely \\
\hline Ability to compete with larger firms & Higher billing rates than expected \\
\hline Access to technical resources & Lack of quality control \\
\hline Access to national and international expertise & Payment for services not timely \\
\hline Better trained staff & Referrals not in the amount expected \\
\hline Better able to meet client expectations & Short-term nature of projects \\
\hline Expanded service offerings & Slow response from partner for services requested \\
\hline Increased revenue & Sporadic schedule \\
\hline
\end{tabular}

Table 5 displays the major satisfactions and dissatisfactions with their alliances as reported by the firms in the study. Generally, the respondents agree that their firms benefited from increased service offerings to clients as well as the corresponding increase in revenues both nationally and internationally because of the access to technical and other knowledge-sharing resources from their alliance partners. On the other hand, some firms perceived that their partners were not as capable of performing services as advertised. They also reported experiences of higher billings than contracted, sporadic scheduling, untimely payments, and shorter commitments than promised by the partners.

Another objective of this study was to investigate whether firms embrace and practice total quality management (TQM). Of the 74 firms in the sample, 35 respondents reported that their firms did practice some elements of TQM, (including continuous improvement, benchmarking, employee empowerment, use of crossfunctional teams, and teaching/providing TQM tools to employees), while another 34 noted that their firms did not practice TQM. Twenty-six of the firms that practice TQM were smaller firms with revenues in 2007 of less than $\$ 10$ million. Eight firms reported revenues between $\$ 10$ million and $\$ 50$ million, while the other respondent reported revenues between $\$ 100$ million and $\$ 250$ million.

Table 6 - Firm Size and The Practice of Total Quality Management

\begin{tabular}{|l|c|c|c|c|}
\hline \multicolumn{1}{|c|}{ Firm Size } & Continuous Improvement & \multicolumn{2}{c|}{ Benchmarking } \\
\hline & No. & \% & No. & \% \\
\hline Less than \$10 million & 21 & 70.0 & 13 & 61.9 \\
\hline Between \$10 million and \$50 million & 8 & 26.7 & 7 & 33.3 \\
\hline Between \$50 million and \$100 million & 0 & 0.0 & 0 & 0.0 \\
\hline Between \$100 million and \$250 million & 1 & 3.3 & 1 & 4.8 \\
\hline Total Responses & 30 & $100 \%$ & 21 & $100 \%$ \\
\hline
\end{tabular}

Table 6 provides results of responses on the two major elements of TQM practiced by the respondents, continuous improvement and benchmarking. The implications clearly indicate that, given the competitive nature of their business, the services firms provide to their clients must not only measure up to professional standards, but must also be continuously improved for firms to survive and prosper. 


\section{SUMMARY AND CONCLUSION}

This paper reports on the results of a survey investigating the state of strategic alliances in public accounting firms. This topic is especially important especially in light of the need for transparency and integrity in financial reporting and disclosures. The accounting regulations passed during the last decade have forced many CPA firms to outsource specialized services to other firms with the expertise and resources to perform them. Among the various satisfactions achieved from their collaborations, the significant findings of the study of 46 formal alliances indicate that the firms were able to: (1) pool their resources, (2) increase their revenues, (3) build a larger knowledge support system to serve a wider clientele, and (4) compete with larger firms, both nationally and on a global basis.

The results of this study make a valuable contribution to the accounting literature. While it supports the findings of prior studies on strategic alliances that firms benefit from an access to resources that could lead to an increase in new product development, thereby enhancing a company's chances for survival and success (Deeds \& Hill, 1996), it is probably the first study to document the experiences of CPA firms with these inter-firm cooperations. Further research could explore the state of strategic alliances between U.S. CPA firms and foreign firms to determine their effects on firm performance, as well as to identify any communication or other barriers that may hinder the effectiveness of learning and knowledge-sharing across firms.

\section{AUTHOR INFORMATION}

Huldah A. Ryan, Ph.D., MBA, is Professor of Accounting in the Hagan School of Business at Iona College in New Rochelle, NY. She received her BA in General Studies from the University of the West Indies, her MBA from Texas Southern University, and Ph.D. from the University of Houston. Her research interests include strategic alliances, CEO compensation, and corporate governance and has published articles in a variety of business journals. She currently serves as Associate Editor of the Journal of Theoretical Accounting Research and teaches courses in Accounting Principles and Intermediate Accounting.

Charles J. Cante, Ph.D., MBA, CQE, is Associate Dean and MBA Program Director and Professor of Information Systems in the Hagan School of Business at Iona College in New Rochelle, NY. He is a former Vice President of Technology and Engineering and subsequently of Quality and Purchasing in which role he was responsible for the development of strategic alliance with suppliers.

Robert G. Strittmatter, MBA, CPA, is Associate Professor of Accounting and Chair of the Accounting Department in the Hagan School of Business at Iona College in New Rochelle, NY. He teaches courses in Accounting Principles and Cost Accounting and has professional experience in public accounting and internal auditing. His research interests include professional accounting practice, social security and the federal budget.

Dr. Vincent J. Calluzzo, Ph.D., MS, is Dean and Professor of Information Systems at the Hagan School of Business at Iona College in New Rochelle, NY. He received his Ph.D. in Operations Research, an MS in Applied Mathematics and a BS in Aerospace Engineering, each from the Polytechnic University. He also has an MS in Education from Queens College of the City University of New York. He is a technology consultant and his research interests include strategic management issues and asset pricing.

Caitlin R. Maxwell is a graduate assistant in the Hagan School of Business at Iona College and conducted research for the paper. Caitlin is currently pursuing an MBA in financial management. Prior to her graduate studies, Caitlin graduated from Iona with a BBA in accounting. Upon completion of her MBA, Caitlin plans to begin her career as an auditor at Ernst and Young.

\section{REFERENCES}

1. Brannback, M (1997). "The Knowledge-Based Marketing Concept: A Basis for Global Business.” Human Systems Management 16 (4): 293-299. 
2. Dyer, J.H, Kale, P. and H. Singh (2001). "How to Make Strategic Alliances Work." MT Sloan Management Review 42 (4): 37-43.

3. Gamal, Irv (2002). "Make Strategic Relationships a Success.” Journal of Accountancy 194 (3): 53-56.

4. Glickman, R. (2000). "International Associations.” Journal of Accountancy 189 (1): 41-46.

5. $\quad$ Gulati, R (1998). “Alliances and Networks.” Strategic Management Journal 19 (4): 293-317.

6. Hwang, Y. and Seung Ho Park (2007). "The Organizational Life Cycle as a Determinant of Strategic Alliance Tactics: Research Propositions." International Journal of Management 24 (3): 427-436.

7. Inkpen, A.C. (1998). "Learning and Knowledge Acquisition Through International Strategic Alliances." Academy of Management Executive 12 (4): 69-80.

8. _ (1996). "Creating Knowledge Through Collaboration." California Management Review 39 (1): 123-140.

9. Ireland, RD, Hitt, M.A. and D. Vaidyanath (2002). "Alliance Management as a Source of Competitive Advantage." Journal of Management 28 (3): 413-446.

10. Kazanjian, R.K. and R. Drazin(1990). "A Stage-Contingent Model of Design and Growth for Technology Based New Ventures." Journal of Business Venturing 5: 137-150.

11. Kotler, P (2000). Marketing Management. Prentice Hall, Upper Saddle River, NJ.

12. Mayer, K.J. and David J. Teece (2008). "Unpacking Strategic Alliances: The Structure and Purpose of Alliance Versus Supplier Relationships.” Journal of Economic Behavior and Organizations 66 (1): 106.

13. Parise, S. and J.C. Henderson (2001). "Knowledge Resource Exchange in Strategic Alliances." IBM Systems Journal 40 (4).

14. www.research.ibm.com 


\section{NOTES}

